\title{
Nest-moving by the polydomous ant Cataglyphis iberica
}

\author{
Abdallah Dahbi \& Javier Retana \& Alain Lenoir \& \\ Xim Cerdá
}

\begin{abstract}
In this paper we analyze emigration from nests by the polydomous ant Cataglyphis iberica. Social carrying of workers of this species between different nests of the colony is frequent. In Bellaterra (Barcelona, NE Spain), we monitored field emigration of C. iberica by noting for each nest the migratory behavior of C. iberica workers and, when the nests were attacked by another ant species, Camponotus foreli, we noted the number of C. foreli workers involved in the attacks. Emigration of C. iberica from nests was highly variable. We suggest the main factor determining emigration by this species was attack by workers of C. foreli, so emigration from C. iberica nests was much faster when harassment by C. foreli increased. The system of multiple nests of C. iberica enables this species to abandon attacked nests and to reinstall their population in other nests of the same colony. This reduces
\end{abstract}

\footnotetext{
A. Dahbi

Faculté Poly-disciplinaire,

Département des Sciences de la Vie et de la Terre,

Université Caddi Ayyad, Safi, Morocco

J. Retana (\&)

Unitat d'Ecologia i CREAF, Facultat de Ciències,

Universitat Autònoma de Barcelona,

08193 Bellaterra, Barcelona, Spain

e-mail: Javier.Retana@uab.es
}

\author{
A. Lenoir · X. Cerdá \\ IRBI, Institut de Recherches sur la Biologie de l'Insecte, UMR \\ CNRS 6035, Université François Rabelais de Tours, Faculté des \\ Sciences, Parc de Grandmont, 37200 Tours, France \\ X. Cerdá \\ Estación Biológica de Doñana, CSIC, Apdo. 1056, \\ 41080 Sevilla, Spain
}

risk to the colonies because the route between the different nests is well known by transporter workers.

Keywords Ant - Nest emigration - Social carrying · Polydomy · Harassment · Cataglyphis iberica · Camponotus foreli

\section{Introduction}

Nests provide ant colonies with a physical refuge from predators and independence from environmental conditions, allowing nest members homeostasis. Although ant nests have frequently been treated as spatially fixed structures, a fact which has led to parallels being established between ant colonies and plants (Andersen 1991; López et al. 1994), unlike plants, ant colonies are not completely sessile, and colonies of many ant species relocate to more favorable nest sites, some species being completely nomadic or semi-nomadic. In fact, ant colonies move from one site to another more frequently than previously imagined (Hays et al. 1982; Smallwood 1982a; Herbers 1985; Tsuji 1988; Gordon 1992; Briano et al. 1995; Tinaut et al. 1999). It is being increasingly recognized that nest relocation is an important aspect of the behavior in many ant species (Smallwood 1982b; Tsuji 1988; Brown 1999; McGlynn et al. 2004). Ants abandon their nests when confronted with environmental changes (Fukumoto and Abe 1983; Hölldobler 1984; Yamaguchi 1992; Gibb and Hochuli 2003), when attacked by other ants or predators (Mabelis 1979; LaMon and Topoff 1981; Droual 1984; Yamaguchi 1992), when the nest cavity cannot be enlarged (Gobin et al. 1998), or in seasonal cycles, because colonies of some polydomous species overwinter as a unit and break up into nest fractions during the active season (Traniello 
and Levings 1986; Herbers 1986, 1989; Banschbach and Herbers 1999).

According to Hölldobler and Wilson (1990), colony emigration is basic to ant biology-surprisingly frequent in occurrence and vital to survival. Movement of workers from one to another nest is, presumably, because of a balance between the costs and benefits of relocation (reviewed by Tsuji 1988). Nest evacuation is a disruptive and costly strategy. Costs may include loss of foraging time, energy expended excavating and managing new nests, and exposure of the colony queen to surface predation by birds, lizards, and other invertebrates (Brown 1999; Pezon et al. 2005). For many ant species nest movement is mediated by stereotyped techniques of communication and transportation (reviewed by Hölldobler and Wilson 1990). Many ant species emigrate along trails, following chemical marks (Harrison and Gentry 1981; Droual 1983; Aron 1992; Djiéto-Lordon et al. 2001). In other instances nest moving involves behavior such as tandem running, in which a recruiter slowly leads a single ant from the old nest to the new (Möglich 1978, Pratt et al. 2002), and social carrying, in which an ant, the transporter, picks up a nest-mate, the transportee, and carries it to the new site (Abraham and Pasteels 1980; Kwait and Topoff 1983; Pratt 1989; Langridge et al. 2004). Species using chemical communication have many means of modulating the intensity of the recruitment signal according to the stimulus (Beckers et al. 1992, 1993; Portha et al. 2002). For other species, nestmate leading is not linked to chemical signals, and its modulation is strictly behavioral, e.g. changing from tandem-running to social carrying (Möglich and Hölldobler 1974; Pratt et al. 2002) or by task switching when necessary (Sendova-Franks et al. 2002).

One ant species for which nest-mate transport is not linked to chemical signals is Cataglyphis iberica, which is endemic to the Iberian Peninsula and lives in arid and very dry locations (Tinaut and Plaza 1989). C. iberica colonies are monogynous and polydomous (Cerdá et al. 1994, 2002). Monogyny is a relatively uncommon trait in polydomous colonies, because in most ant species polydomy is linked to polygyny (Pisarski 1972; Yamauchi et al. 1981; Rosengren and Pamilo 1983; Rosengren et al. 1993; Pedersen and Boomsma 1999). Nests of C. iberica colonies (one of which has the single queen), are connected by social carrying (Cerdá et al. 1994; Fourcassié et al. 2000). For this species, adult transport between nests is involved in the maintenance of a homogeneous colony odor, or "gestalt odor" (Dahbi et al. 1997), and in emigration from nests (Cerdá and Retana 1998), and is performed by a few workers belonging to a temporary caste that specializes in transporting nest-mates (Cerdá and Retana 1992). Our objective in this paper is to describe emigration of this species from nests, and its modulation in different circumstances. Cataglyphis iberica lives in places where competition with other species is intense. Here we study emigration in the presence of Camponotus foreli in particular.

\section{Materials and methods}

Fieldwork was conducted in Bellaterra, near the campus of the Autonomous University of Barcelona (Barcelona, NE Spain) during the summer. The climate in the area is Mediterranean subhumid, and soil is calcareous of the xerorthent type. The study site was characterized by the total absence of overstory stratum and a reduced understory and herbaceous cover. Because emigration was an unpredictable phenomenon, it was not possible to know the site where it would happen, or the moment, to enable the study to be performed systematically. All occurrences of emigration observed in the study area were monitored until their end. Monitoring was conducted by two observers who noted, for each C. iberica nest and for the whole duration of each episode, the migratory behavior of C. iberica workers (number of transports of workers or brood during 5 min every $10 \mathrm{~min}$ ) and the nest of destination of this transport. The timing of the emigration of the queen was of particular interest, because it may be hypothesized that early transport of the queen would be the least risky option. As emigration progresses it is likely to attract greater attention from predators with time. Soil temperature (near the nest entrance, in the sun) was recorded every hour with glass-headed thermocouples connected to a Univolt DT-830 digital multimeter. Because some emigrations were provoked by attacks by another ant species, Camponotus foreli, intensity of harassment in the course of emigration was quantitatively estimated (high, low, or none) from the number of $\mathrm{C}$. foreli workers involved in attacks against $\mathrm{C}$. iberica nests.

\section{Results}

Descriptive statistics of emigration of C. iberica from nests are listed in Table 1. Most emigrations occurred at approximately noon on summer days, when temperatures were highest and C. iberica was the only ant species present on the ground. Emigrations were conducted by transport of workers (and brood) from the abandoned nest to other nests of the same colony. The number of nests that received these transports varied from one to four but frequently one nest received most of the transported workers. Emigration lasted between 1 and $2 \mathrm{~h}$ (only considering episodes observed completely). The distance between the original and the receiving nests did not affect the duration 
Table 1 Characteristics of emigration from Cataglyphis iberica nests

\begin{tabular}{|c|c|c|c|c|c|c|}
\hline Emigration number & 1 & 2 & 3 & $4^{*}$ & $5^{*}$ & 6 \\
\hline Time of the day (LST) & $12: 30$ & $12: 50$ & $12: 15$ & $(14: 40)$ & $(13: 05)$ & $12: 00$ \\
\hline Date & 1 June 1988 & 10 August 1983 & 12 August 1987 & 29 July 1987 & 4 August 1988 & 13 August 1987 \\
\hline Observation time (min) & 125 & 70 & 90 & $(25)$ & (55) & 60 \\
\hline Mean temperature $\left({ }^{\circ} \mathrm{C}\right)$ & 38 & 48 & 50 & 50 & 45 & 44 \\
\hline Total observed transports & 302 & 104 & 182 & 198 & 342 & 541 \\
\hline Number of recipient nests & 4 & 1 & 1 & 1 & 2 & 2 \\
\hline Distance of travel (m) & 2.3 & 1.1 & 3.3 & 1.9 & 2.8 & 3.3 \\
\hline Mean velocity (transports per min) & 2.4 & 1.2 & 2.0 & 7.9 & 6.2 & 9.0 \\
\hline Nest harassment by C. foreli & None & None & Low & High & High & High \\
\hline Nest occupation by C. foreli & No & No & Yes & No & Yes & Yes \\
\hline
\end{tabular}

Emigrations indicated with an asterisk were not observed from the beginning. Mean temperatures for the times of movement, characteristics of emigration, and intensity of nest harassment by C. foreli are shown for each instance of emigration. Low harassment: fewer than five C. foreli workers attack the nest and do not remain very long at the nest. High harassment: more than five C. foreli workers (between 5 and 25) attack the nest and remain at the nest entrance

of emigration-there was no significant relationship between mean velocity of emigration and distance traveled by adult transports (Spearman's correlation $\mathrm{R}=0.377$, $\mathrm{P}=0.46, \mathrm{n}=6$ ) or between duration of emigration (time with traffic of adult transports) and distance (Spearman's correlation $\mathrm{R}=-0.211, \mathrm{P}=0.79, \mathrm{n}=6$ ). When abandonment of the nest was provoked by harassment by $\mathrm{C}$. foreli workers, mean velocity was significantly higher (ANOVA, $\mathrm{F}=43.2, \mathrm{P}=0.003$ ) than when there was little or no harassment $(7.7 \pm 0.6$ and $1.9 \pm 0.6$ transports per min, respectively, $n=3$ for both). In three out of six instances the nest was later occupied by C. foreli workers.

Figure 1 shows details of six emigrations (data have been standardized for comparison) indicating the different patterns observed, depending on the cause of emigration. Three cases (1-3) are emigrations from nests not attacked by C. foreli. For these emigrations recruitment of adult transports begins slowly, more than $2 \mathrm{~h}$ elapsing. In case 1 emigration was accelerated when the queen was carried to the receiving nest. In the other cases we did not observe transport of the queen. In cases 4-6, emigrations were caused by C. foreli harassment, and they quickly attained high values of adult transport, a large slope is apparent in the graphical representation. Most (80\%) of the population of each nest is carried in a very short time, up to $90 \mathrm{~min}$.

A case study is described to illustrate the development of emigration with harassment. It affected a C. iberica colony which, on 15 July, consisted of three nests related by social carrying (Fig. 2a). On 29 July, Nest 3 had already been abandoned and Nest 2 was harassed by C. foreli workers that were at the entrance attacking and biting returning C. iberica foragers. Nest 1 received all transports from Nest 2, which was abandoned on 3 August. On 11 August, the colony was composed of Nests 1 and 4, which colony workers had excavated on previous days. The two

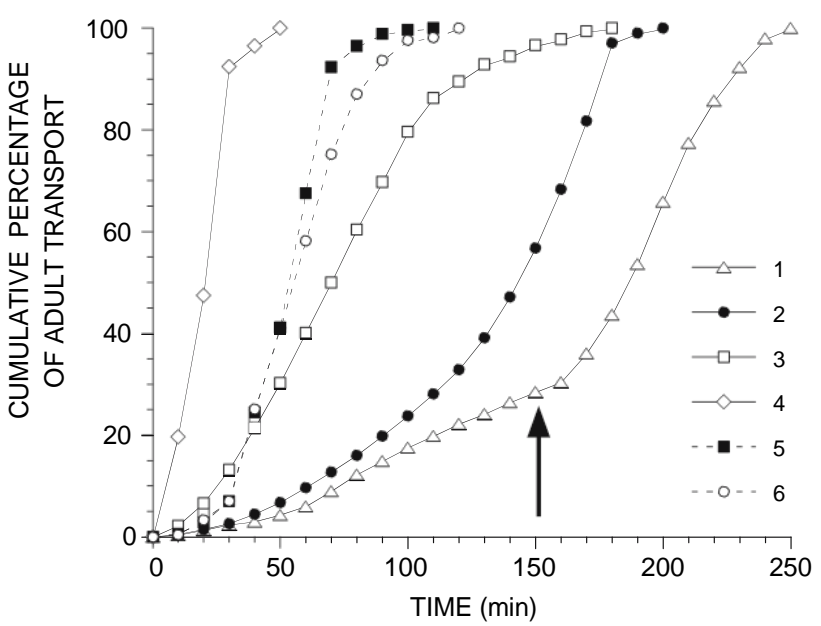

Fig. 1 Nest abandonment during the six instances of emigration of Cataglyphis iberica observed in the field (cumulative percentage of adult transport through time). Cases 1-3 were not affected or only weakly affected by C. foreli attacks whereas cases 4-6 occurred after intense C. foreli harassment (more details of each episode are given in Table 1). Transports were quantified during 5 min for each 10 min. Time is the time since the first adult was transported from the nest. The arrow indicates queen transport

nests were attacked by C. foreli workers, which tried to open the nests, while C. iberica workers blocked up the entrance with sand from inside. This behavior continued the next day and after 12:00 p.m. occupants of Nest 1 were forced to emigrate to Nest 4 (Fig. 2b). There was also much digging activity in two new nests, Nests 5 and 6, and several transports arrived at the former. On 13 August (Fig. 2c), C. foreli workers attacked Nest 4 . The number of attacking C. foreli workers, which was high during the morning hours, decreased after 11:30 a.m., because of the high temperatures reached on the ground. At 12:00 a.m., 
Fig. 2 Development of an episode of harassment of a Cataglyphis iberica colony by two Camponotus foreli nests (F1 and F2). The polydomous colony was initially composed of three nests (Nests 1, 2 and 3), that split into eight new nests (Nests 4-11) as a consequence of C. foreli attacks. Dates: a 15 July; b 12 August; c 13 August; d 20 August. Unbroken line with an arrow at the end, emigration by adult transport from one nest to another. Unbroken line with arrows at both ends, within-colony nest relationships by adult transport. >>: attack of C. iberica nest by C. foreli. EX, new nest excavation by $\mathrm{C}$. iberica workers
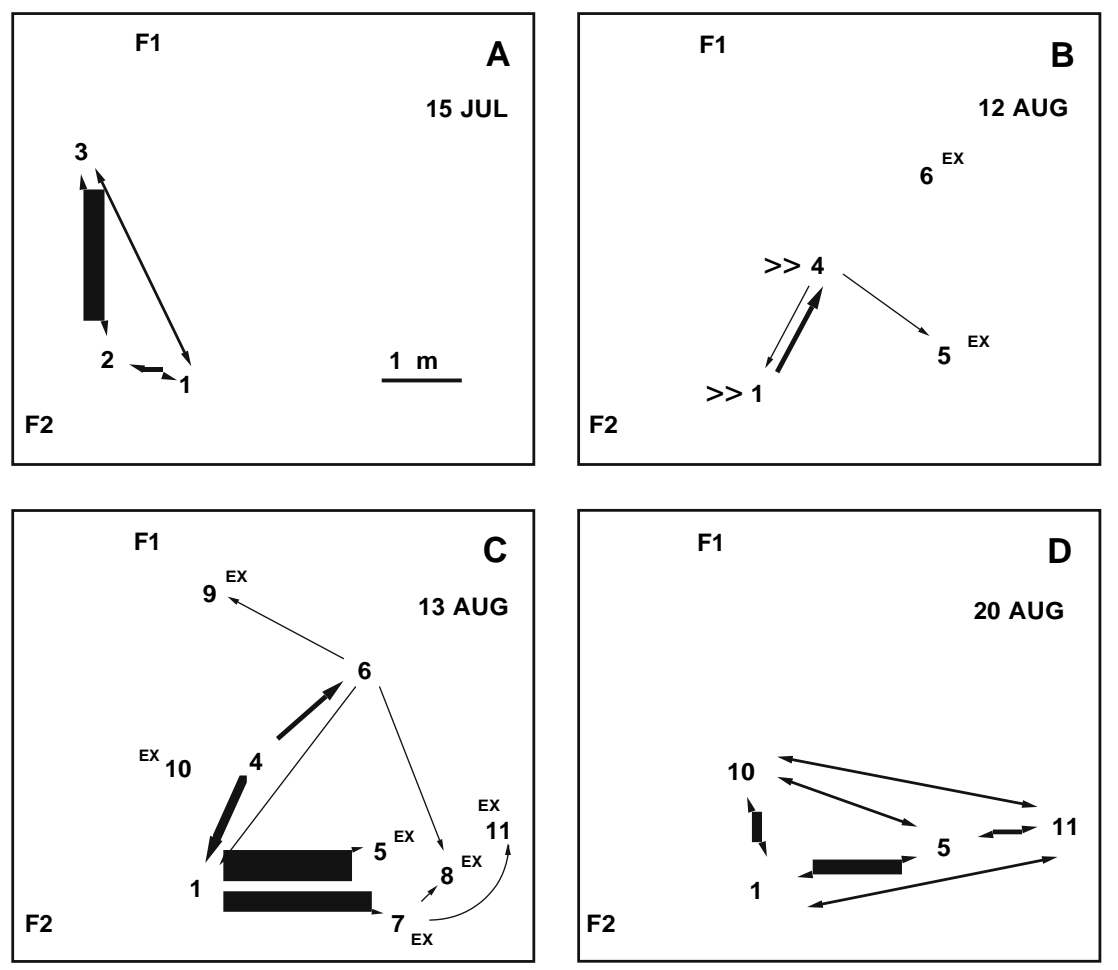
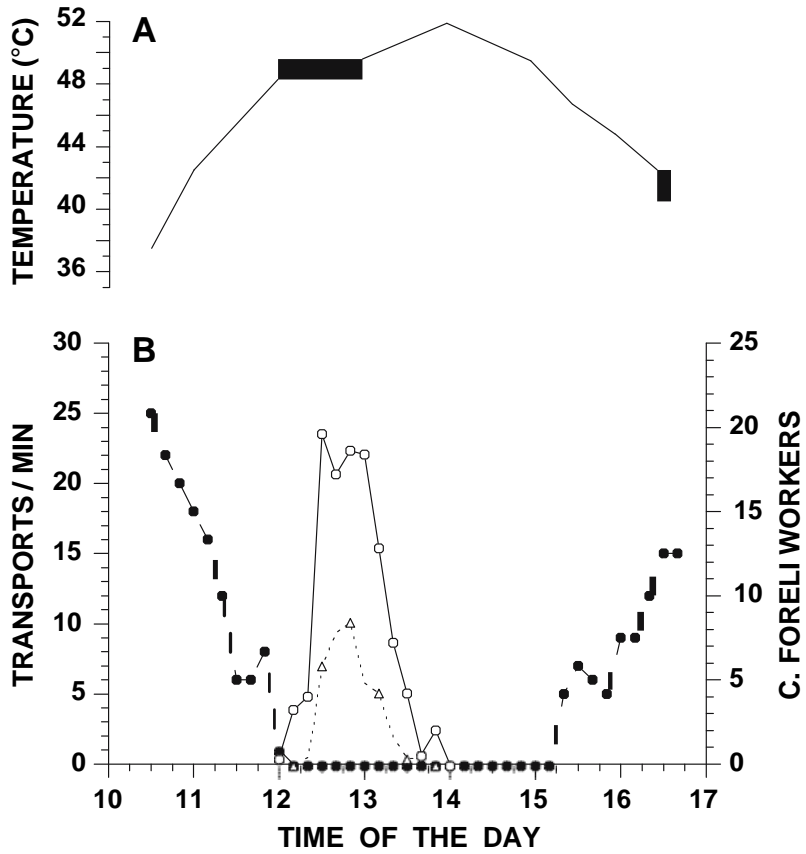

Fig. 3 a Daily fluctuation of soil surface temperature $\left({ }^{\circ} \mathrm{C}\right)$ during (b) abandonment of a C. iberica nest caused by the attacks of $\mathrm{C}$. foreli. Time is local standard time (GMT $+2 \mathrm{~h}$ ). Solid dots (and right scale) represent the number of $\mathrm{C}$. foreli workers at the entrance of the attacked C. iberica nest. The critical thermal limits, CTM, of C. foreli and C. iberica are, respectively, 48 and $52^{\circ} \mathrm{C}$. On the left scale, open triangles (and broken lines) indicate brood transports, and open dots (and solid line) indicate adult transports (number per minute) by C. iberica workers to other nests of the polydomous colony when ground temperature exceeded $48^{\circ} \mathrm{C}$, almost no C. foreli were found near the nest entrance (Fig. 3). At that time C. iberica workers evacuated the nest by means of brood and worker transports (with up to eight brood transports and 19 worker transports per minute). These transports were in two directions, mainly to Nest 1 , but also to Nest 6. Abandonment of Nest 4 was complete in less than $2 \mathrm{~h}$. When the temperature decreased and C. foreli workers returned to the nest entrance at approximately 15:00 p.m. the nest was almost empty. During this day, much digging activity was observed in Nest 5 and in other new nests (Nests 7, 8, 9, 10, and 11). Harassment of C. iberica nests had finished by 14 August, and the remaining nests had either normal foraging activity (Nests 4, 6 and 8) or digging activity (Nests 1, 5, 10 and 11). When all nests were excavated by us (one week after the end of the attack), Nests 1, 5, 10 and 11 had workers and brood, with the queen in Nest 11, and Nests 2, 3, 4, 5, 7, 8 and 9 were empty. Thus, the final outcome of this harassment was displacement of the C. iberica colony by a few meters but not its destruction. After these attacks and emigration episodes the queen was, moreover, lodged in the nest (Nest 11) furthest from C. foreli nests (Fig. 2d).

\section{Discussion}

Nest moving by ants occurs at unpredictable times. This makes them very difficult to observe in the field and 
explains why descriptive statistics are relatively rare in the literature. The data provide, nonetheless, an illustration of the effect on ants of interference competition. Harassment by C. foreli is an important reason for nest moving by C. iberica in the habitat studied. From our results we conclude that time taken during emigration of C. iberica depends on the level of harassment. When necessary, nests are quickly abandoned, the worker force moving to another nest of the same colony by means of adult transport.

Emigration of ant societies may be a costly strategy, but it is necessary when the nest becomes uninhabitable for different reasons (destruction, environmental changes, pressure from predators or competitors, etc.). To understand nest evacuation it is necessary to evaluate the costs and benefits for the colony. When nest construction is easy because of its simplicity and the colony is small, as it is for C. iberica (Plaza and Tinaut 1989), it is easier to emigrate when external conditions are unfavorable (Möglich 1978; Hölldobler 1984). C. iberica colonies are polydomous, and social carrying of workers between different nests of the colony is frequent (Cerdá et al. 1994). Although social carrying was originally a recruitment system for emigration of ants from nests (Wilson 1971), for C. iberica this behavior also serves to maintain colony cohesion (Dahbi et al. 1997) and to increase habitat exploitation (Cerdá et al. 2002). Nest movement is high in this species; the lifetime of up to $55 \%$ of nests is only 1-3 months (Cerdá et al. 2002), and when nest renewal occurs, workers and brood are transported to other nests of the colony by social carrying. The multi-nest system of C. iberica reduces the risks run by the colonies, because the receiving nest is already excavated and the route between the different nests is well known by transporter workers, which transport adults and brood by social carrying between nests throughout the foraging season (Cerdá et al. 1994). For many ant species there is an exploration period before nest moving (Abraham and Pasteels 1980; Fukumoto and Abe 1983; Kumar and Veeresh 1990; Verhaeghe et al. 1992) but for C. iberica the exploration period is not necessary and emigration time is shorter (we have observed a maximum of $2 \mathrm{~h}$ for emigration of C. iberica; Table 1, Fig. 3).

One of the key factors affecting emigration from nests is transport of the queen. Nest movement is a potentially dangerous time for a colony, because queens (and also brood) are exposed to predators when they travel on the surface between nest sites (Levings 1983). Transport of the queen in the middle of emigration, as has been observed for some ant species (Franks and Sendova-Franks 2000; Pezon et al. 2005) could be a lower-risk strategy, because she is transferred from the protection of half of the colony in the old nest to protection of the other half in the new nest (Franks and Sendova-Franks 2000), but it can also be a risky option, because as emigration progresses it is likely to attract greater attention from predators. In the only instance in which transport of the C. iberica queen was observed it provoked acceleration of worker transports, in contrast with the observed behavior of Myrmica rubra (Abraham and Pasteels 1980). Because C. iberica colonies are monogynous, with a central nest that contains the only queen and centralizes the interchange of workers by adult transport (Cerdá et al. 1994), the queen is a key factor promoting activation of adult transport by transporter workers, when it is in certain danger during emigration from a nest.

Emigration of C. iberica from nests is highly variable, however (Table 1 ; Fig. 1). One factor causing emigration of this species from a nest is the attack by $\mathrm{C}$. foreli workers (a complete description of the harassment of C. iberica colonies by C. foreli is available elsewhere (Cerdá and Retana 1998)). The results given above indicate that emigration of C. iberica from nests is much faster when harassment by $\mathrm{C}$. foreli increases. Both $\mathrm{C}$. foreli and C. iberica are heat-tolerant and risk-prone ant species (Cerdá et al. 1998) that forage when temperatures are closer to their critical thermal limits. The specificity of antagonistic behavior between these species can be seen as an example of "enemy specification"' (Wilson 1976), because C. foreli attacks have the outcome of nest usurpation, i.e. they usually occupy the abandoned nest after expulsion of C. iberica (Cerdá and Retana 1998) but do not affect other species present in the area, for example Aphaenogaster senilis, a species with similarly low aggression (Retana and Cerdá 1995). C. iberica cannot defend nests against C. foreli, which has larger workers and more aggressive behavior, so rapid nest evacuation is less costly than strong resistance to the invaders (Cerdá and Retana 1998), which may lead to many workers being injured or killed. The greater thermophyly of C. iberica than C. foreli (their critical thermal maximum temperatures are 52 and $48^{\circ} \mathrm{C}$, respectively (Cerdá and Retana, unpublished data)), enables $\mathrm{C}$. iberica workers to abandon the nest without the presence of $\mathrm{C}$. foreli, which are unable to withstand the high soil temperatures (Fig. 3). Because of the harsh conditions and extreme temperatures, adult transport performed by individual foragers is probably more efficient than recruitment by use of chemical trails (Ruano et al. 2000). The system of multiple nests also enables them to abandon the attacked nests and to reinstall their population in other nests of the same colony (Fig. 2). The advantages of polydomy when a nest is suddenly attacked or destroyed by natural events have been observed for different ant species (Mabelis 1979; Droual 1983, 1984; Curtis 1985) and for other social insects, for example wasps (Strassmann 1981; Ito 1986).

If we ignore the peculiar daily migrations of army ants, velocities of emigration are very different both between 
(Möglich 1978; Lamon and Topoff 1981) and within (Mabelis 1979; Pratt et al. 2002; this study) species, ranging from 2-5 to 80-90 workers per minute, depending on nest population. The duration of emigration also depends on nest population but is mainly affected by the cost of nest production, and may last from several tens of minutes (Maschwitz and Schönegge 1983) to a few hours (Longhurst and Howse 1979; Tsuji 1988; Leal and Oliveira 1995; this study) and even days (Smallwood 1982b). Activation of emigration always occurs during the hours of maximum activity of the species, e.g. during the hottest hours of the day for C. iberica, a thermophilic ant (Cerdá and Retana 1988), during the day for Leptogenys nitida (Duncan and Crewe1994), and at night for the nocturnal Leptogenys sp.1 (Maschwitz et al. 1989). As Hölldobler and Wilson (1990) state, in the future it will be exciting to study the phenomenon of emigration from nests more extensively, to correlate the many forms emigration takes with exigencies faced by species in their individual environments. In the last few years laboratory studies have focused on the emigration of Leptothorax societies by use of an interesting combination of decision-making and mathematical modeling (Mallon et al. 2001; Franks et al. 2002, 2003a, b; Sendova-Franks et al. 2002; Pratt et al. 2002; Langridge et al. 2004); as far as we are aware, however, field studies of behavior and ecology are still scarce. C. iberica is a very interesting and special species. It occupies very arid and degraded areas where a network of nests enables it to maximize habitat exploitation (Cerdá et al. 2002). In addition to this ecological advantage of polydomy, when a “problem'” (= attack or destruction) affects a nest, abandonment may be an immediate response.

Acknowledgments This study was partly funded by the Spanish Ministerio de Educación y Ciencia (BOS2003-01536 to X.C.). An earlier version of the manuscript was written during different stays of X.C. and J.R. at the LEEC (Université Paris Nord) supported by Spanish-French grants from MEC (HF93-133B and HF94-345B). X.C.'s stay at IRBI was supported by a sabbatical grant from MEC (PR2004-0539). We are grateful to Rocío Requerey and Elena Angulo for bibliographic assistance.

\section{References}

Abraham M, Pasteels JM (1980) Social behaviour during nest-moving in the ant Myrmica rubra L. (Hymenoptera: Formicidae). Insect Soc 27:127-147

Andersen AN (1991) Parallels between ants and plants: implications for community ecology. In: Huxley CR, Cutler DF (eds) Antplant interactions. Oxford University Press, Oxford, pp 539-558

Aron S (1992) Queen retrieval in the Argentine ant. Experientia 48:694-697

Banschbach VS, Herbers JM (1999) Nest movements and population spatial structure of the forest ant Myrmica punctiventris (Hymenoptera: Formicidae). Ann Entomol Soc Am 92:414-423
Beckers R, Deneubourg JL, Goss S (1992) Trail laying behaviour during food recruitment in the ant Lasius niger (L.). Insect Soc 39:59-72

Beckers R, Deneubourg JL, Goss S, (1993) Modulation of trail laying in the ant Lasius niger (Hymenoptera: Formicidae) and its role in the collective selection of a food source. J Insect Behav 6:751759

Briano JA, Patterson RS, Cordo HA (1995) Colony movement of the black imported fire ant (Hymenoptera: Formicidae) in Argentina. Environ Entomol 24:1131-1134

Brown MJF (1999) Nest relocation and encounters between colonies of the seed-harvesting ant Messor andrei. Insect Soc 46:66-70

Cerdá X, Retana J (1988) Influencia de los factores ambientales sobre la actividad diaria de recolección de la hormiga Cataglyphis iberica (Em.) (Hymenoptera: Formicidae). Anales Biología 15:75-82

Cerdá X, Retana J (1992) A behavioural study of transporter workers in Cataglyphis iberica ant colonies (Hymenoptera, Formicidae). Ethol Ecol Evol 4:359-374

Cerdá X., Retana J (1998) Interference interactions and nest usurpation between two subordinate ant species. Oecologia 113:577-583

Cerdá X, Retana J., de Haro A (1994) Social carrying between nests in polycalic colonies of the monogynous ant Cataglyphis iberica (Hymenoptera: Formicidae). Sociobiology 23:215-231

Cerdá X, Retana J, Cros S (1998) Critical thermal limits in Mediterranean ant species: trade-off between mortality risk and foraging performance. Funct Ecol 12:45-55

Cerdá X, Dahbi A, Retana J (2002) Spatial patterns, temporal variability and the role of multi-nest colonies in a monogynous Spanish desert ant. Ecol Entomol 27:7-15

Curtis BA (1985) Nests of the Namib desert dune ant Camponotus detritus Emery. Insect Soc 32:313-320

Dahbi A, Cerdá X, Hefetz A, Lenoir A (1997) Adult transport in the ant Cataglyphis iberica: a means to maintain a uniform colonial odour in a species with multiple nests. Physiol Entomol 22:1319

Djiéto-Lordon C, Orivel J, Dejean A (2001) Consuming large prey on the spot: the case of the arboreal foraging ponerine ant Platythyrea modesta (Hymenoptera: Formicidae). Insect Soc 48:324-326

Droual R (1983) The organization of nest evacuation in Pheidole desertorum Wheeler and P.hyatti Emery (Hymenoptera: Formicidae). Behav Ecol Sociobiol 12:203-208

Droual R (1984) Anti-predator behaviour in the ant Pheidole desertorum: the importance of multiple nests. Anim Behav 32:1054-1058

Duncan FD, Crewe RM (1994) Group hunting in a ponerine ant, Leptogenys nitida Smith. Oecologia 97:118-123

Fourcassié V, Dahbi A, Cerdá X (2000) Orientation and navigation during adult transport between nests in the ant Cataglyphis iberica. Naturwiss 87:355-359

Franks NR, Sendova-Franks AB (2000) Queen transport during ant colony emigration: a group-level adaptive behavior. Behav Ecol 11:315-318

Franks NR, Pratt SC, Mallon EB, Britton NF, Sumpter DJT (2002) Information flow, opinion polling and collective intelligence in house-hunting social insects. Philos Trans R Soc Lond B Biol Sci 357:1567-1583

Franks NR, Dornhaus A, Fitzsimmons JP, Stevens M (2003a) Speed versus accuracy in collective decision making. Proc R Soc Lond Biol Sci 270:2457-2463

Franks NR, Mallon EB, Bray HE, Hamilton MJ, Mischler TC (2003b) Strategies for choosing between alternatives with different attributes: exemplified by house-hunting ants. Anim Behav $65: 215-223$ 
Fukumoto Y, Abe T (1983) Social organization of colony movement in the tropical ponerine ant, Diacamma rugosum (Le Guillou). J Ethol 1:101-108

Gibb H, Hochuli DF (2003) Nest relocation in the golden spiny ant, Polyrhachis ammon: environmental cues and temporal castes. Insect Soc 50:323-329

Gobin B, Peeters C, Billen J (1998) Colony reproduction and arboreal life in the ponerine ant, Gnamptogenys menadensis (Hymenoptera: Formicidae). Neth J Zool 48:53-63

Gordon DM (1992) Nest relocation in harvester ants. Ann Entomol Soc Am 85:44-47

Harrison JS, Gentry JB (1981) Foraging pattern, colony distribution, and foraging range of the Florida harvester ant, Pogonomyrmex badius. Ecology 62:1467-1473

Hays SB, Horton PM, Bass JA, Stanley D (1982) Colony movement of imported fire ants. J Georgia Entomol Soc 17:266-274

Herbers JM (1985) Seasonal structuring of a North temperate ant community. Insect Soc 32:224-240

Herbers JM (1986) Nest site limitation and facultative polygyny in the ant Leptothorax longispinosus. Behav Ecol Sociobiol 19:115122

Herbers JM (1989) Community structure in north temperate ants: temporal and spatial variation. Oecologia 81:201-211

Hölldobler B (1984) Communication during foraging and nestrelocation in the African stink ant, Paltothyreus tarsatus Fabr. (Hymenoptera: Formicidae, Ponerinae). Z Tierpsychol 65:40-52

Hölldobler B, Wilson EO (1990) The ants. Springer, Heidelberg

Ito Y (1986) Social behaviour of Ropalidia fasciata (Hymenoptera: Vespidae) females on satellite nests and on a nest with multiple combs. J Ethol 4:73-80

Kumar ARV, Veeresh GK (1990) Nesting, nest shifting and foraging habits of Leptogenys diminuta. In: Veeresh GK, Kumar ARV, Shivashankar $\mathrm{T}$ (eds) Social insects: an indian perspective. IUSSI Indian chapter, Bangalore, pp 108-115

Kwait EC, Topoff H (1983) Emigrations raids by slave-making ants: a rapid-transit system for colony relocation. Psyche 90:307-312

LaMon B, Topoff H (1981) Avoiding predation by army ants: defensive behaviours of three ant species of the genus Camponotus. Anim Behav 29:1070-1081

Langridge EA, Franks NR, Sendova-Franks AB (2004) Improvement in collective performance with experience in ants. Behav Ecol Sociobiol 56:523-529

Leal IR, Oliveira PS (1995) Behavioral ecology of the neotropical termite-hunting ant Pachycondyla (=Termitopone) marginata: colony founding, group-raiding and migratory patterns. Behav Ecol Sociobiol 37:373-383

Levings SC (1983) Seasonal, annual, and among-site variation in the ground ant community of a deciduous tropical forest: some causes of patchy species distribution. Ecol Monogr 53:435-455

Longhurst C, Howse PE (1979) Foraging, recruitment and emigration in Megaponera foetens (Fab.) (Hymenoptera: Formicidae) from the Nigerian Guinea savanna. Insect Soc 26:204-215

López F, Serrano JM, Acosta FJ (1994) Parallels between the foraging strategies of ants and plants. Trends Ecol Evol 9:150-153

Mabelis AA (1979) Nest splitting by the red wood ant (Formica polyctena Foerster). Neth J Zool 29:109-125

Mallon EB, Pratt SC, Franks NR (2001) Individual and collective decision-making during nest site selection by the ant Leptothorax albipennis. Behav Ecol Sociobiol 50:352-359

Maschwitz U, Schönegge P (1983) Forage communication, nest moving recruitment, and prey specialization in the oriental ponerine Leptogenys chinensis. Oecologia 57:175-182

Maschwitz U, Steghaus-Kovac S, Gaube R, Hänel H (1989) A South East Asian ponerine ant of the genus Leptogenys (Hym., Form.) with army ant life habits. Behav Ecol Sociobiol 24:305-316
McGlynn TP, Carr RA, Carson JH, Buma J (2004) Frequent nest relocation in the ant Aphaenogaster araneoides: resources, competition, and natural enemies. Oikos 106:611-621

Möglich M (1978) Social organization of nest emigration in Leptothorax (Hymenoptera: Formicidae). Insect Soc 25:205-225

Möglich M, Hölldobler B (1974) Social carrying behavior and division of labor during nest moving in ants. Psyche 81:219-236

Pedersen JS, Boomsma JJ (1999) Genetic analysis of colony structure in polydomous and polygynous ant populations. Biol J Linn Soc 66:115-144

Pezon A, Denis D, Cerdan P, Valenzuela J, Fresneau D (2005) Queen movement during colony emigration in the facultatively polygynous ant Pachycondyla obscuricornis. Naturwiss 92:35-39

Pisarski B (1972) La structure des colonies polycaliques de Formica (Coptoformica) exsecta Nyl. Ekol Pol 20:111-116

Plaza J, Tinaut A (1989) Descripción de los hormigueros de Cataglyphis rosenhaueri (Emery,1906) y Cataglyphis iberica (Emery,1906) en diferentes biotopos de la provincia de Granada (Hymenoptera: Formicidae). Boletín Asoc Esp Entom 13:109116

Portha S, Deneubourg JL, Detrain C (2002) Self-organized asymmetries in ant foraging: a functional response to food type and colony needs. Behav Ecol 13:776-781

Pratt SC (1989) Recruitment and other communication behavior in the ponerine ant Ectatomma ruidum. Ethology 81:313-331

Pratt SC, Mallon EB, Sumpter DJT, Franks NR (2002) Quorum sensing, recruitment, and collective decision-making during colony emigration by the ant Leptothorax albipennis. Behav Ecol Sociobiol 52:117-127

Retana J, Cerdá X (1995) Agonistic relationships among sympatric Mediterranean ant species (Hymenoptera: Formicidae). J Insect Behav 8:365-380

Rosengren R, Pamilo P (1983) The evolution of polygyny and polydomy in mound-building Formica ants. Acta Entomol Fennica 42:65-77

Rosengren R, Sundström L, Fortelius W (1993) Monogyny and polygyny in Formica ants: the result of alternative dispersal tactics. In: Keller L (ed) Queen number and sociality in insects. Oxford Science Publications, Oxford, pp 308-333

Ruano F, Tinaut A, Soler JJ (2000) High surface temperatures select for individual foraging in ants. Behav Ecol 11:396-404

Sendova-Franks AB, Franks NR (2002) The role of competition in task switching during colony emigration in the ant Leptothorax albipennis. Anim Behav 63:715-725

Smallwood J (1982a) The effect of shade and competition on emigration rate in the ant Aphaenogaster rudis. Ecology 63:124134

Smallwood J (1982b) Nest relocations in ants. Insect Soc 29:138-147

Strassmann JE (1981) Evolutionary implications of early male and satellite nest production in Polistes exclamans colony cycles. Behav Ecol Sociobiol 8:55-64

Tinaut A, Fernández-Escudero I, Ruano F, Cerdá X (1999) The relationship of nest rock dimensions to reproductive success and nest permanence in a high-mountain ant, Proformica longiseta (Hymenoptera: Formicidae). Sociobiology 34:99-117

Traniello JFA, Levings SC (1986) Intra- and intercolony patterns of nest dispersion in the ant Lasius neoniger: correlations with territoriality and foraging ecology. Oecologia 69:413-419

Tsuji K (1988) Nest relocations in the Japanese queenless ant Pristomyrmex pungens Mayr. (Hymenoptera: Formicidae). Insect Soc 35:321-340

Verhaeghe JC, Selicaers N, Deneubourg JL (1992) Nest-moving and food location in Tapinoma erraticum (Hymenoptera, Formicidae). In: Billen J (ed) Biology and evolution of social insects. Leuven University Press, Leuven, pp 335-342 
Wilson EO (1971) The insect societies. Belknap Press of Harvard University Press, Cambridge

Wilson EO (1976) The organization of colony defense in the ant Pheidole dentata Mayr (Hymenoptera: Formicidae). Behav Ecol Sociobiol 1:63-81

Yamaguchi T (1992) Interspecific interference for nest sites between Leptothorax congruus and Monomorium intrudens. Insect Soc 39:117-127
Yamauchi K, Kinomura K, Miyake S (1981) Sociobiological studies of the polygynic ant Lasius sakagamii. 1. General features of its polydomous system. Insect Soc 28:279-296 